\title{
A Failed Politician, a Disputed Jesuit: Cardinal Johann Eberhard Nithard (1607-81)
}

\author{
Miguel Córdoba Salmerón \\ Facultad de Teología de Granada, Granada, Spain \\ mcordoba@teol-granada.com
}

\begin{abstract}
One of the most controversial Jesuit cardinals was Johann Eberhard Nithard, not only because of the intriguing circumstances of his promotion, but also because he was a favorite of Queen Mariana of Austria, regent of Spain and mother of King Charles II. The aim of this essay is to examine a series of events in Nithard's life, focusing in particular on the details surrounding his consecration as bishop and creation as cardinal. This task is performed through an analysis of various sources, many of whichincluding the Jesuit ones- have been responsible for forging Nithard's black legend, which resulted in his eventual expulsion from Spain and in distorted narratives of historians of Nithard's role in the church and state politics in the seventeenth century.
\end{abstract}

\section{Keywords}

Spanish Embassy Rome - Jesuit cardinal - Johann Eberhard Nithard - diplomacy Catholic Church - seventeenth century

Who was Johann Eberhard Nithard (1607-81)? Who was this royal favorite ( $v a$ lido) of Regent Mariana of Austria (1665-75)? Who was this Jesuit who became a cardinal? The way in which we answer these questions ultimately depends on the sources we consult, many of which have been responsible for forging Nithard's black legend, the source of his eventual expulsion from Spain. Indeed, so well-articulated is this black legend in the sources that many scholars, and even some Jesuits, have simply taken it for granted, thus explaining its persistence up to the present day. Antonio Astraín (1857-1928), for example, saw Nithard as “a Jesuit transplanted by the Queen's will into the field of politics; 
completely immersed in public business for three years and kidnapped by it."1 Yet, conversely, if we were to examine Nithard's memoirs, which he wrote at the end of his life - twenty-one volumes in total — we would form an equally distorted image of our subject, because they also present a largely embellished view of himself, albeit one taken to an almost diametrically opposed, positive extreme.

My aim in this essay is to examine a series of historical events in Nithard's life, focusing in particular on the details surrounding his consecration as bishop and creation as cardinal. As we will see in this paper, Nithard is an elusive character, so much so that almost anyone can create their own image of him, as Professor Julián Lozano has done, describing him as "a religious who blindly trusted in Providence and who never came to understand the complexities of palatial life."2 However, before we approach the biographical information, let us examine two paintings that we have of him, both different from each other in quality and style. The first is a work he commissioned, whereas the other is a portrait that was made for the dining room of the Jesuit community at Loyola (Guipúzcoa, Spain).

The first painting is housed at the headquarters of the State Council of Madrid, Spain, although it belongs to the collection of the Museo Nacional del Prado (Madrid, Spain). Nithard commissioned Alonso del Arco (1635-1704) to paint the portrait during his stay in Rome, as the work was dated 1674, two years after Nithard was made a cardinal, while he was still an extraordinary ambassador of Spain in the Eternal City.

Cardinal Nithard appears inside a room, through a large baroque curtain that opens to a terrace overlooking a garden, sitting in a wide and austere armchair furnished in red, looking at the viewer with a serene and simultaneously reflective look. His left arm rests on the armrest, and with his right hand he holds a pen. It seems that he is about to write on the notebook, the pages of which are currently blank. On the table - covered by a red cloth on which the family shield has been painted - there are three books: one by Saint Thomas Aquinas (1225-74), another by Lirillus, and a third one, of which we are unable to see the spine. In the background stands a bookshelf with twelve books on theology, the authors of which are indicated on the spine: Saint Augustine (354-430), Saint Ambrose (c.339-97), Saint Jerome (c.347-419/420), Saint Anselm (1033/34-1109), Saint John Damascene (c.675-749), Saint Ildefonso

1 Antonio Astraín, Historia de la Compañía de Jesús en la asistencia de España (Madrid: Razón y Fe, 1920), 6:102.

2 Julián J. Lozano Navarro, "Una embajada controvertida: El padre Nithard en Roma (16701681)," Roma moderna e contemporánea 1-3 (January-December 2007): 271-91, here 283. 


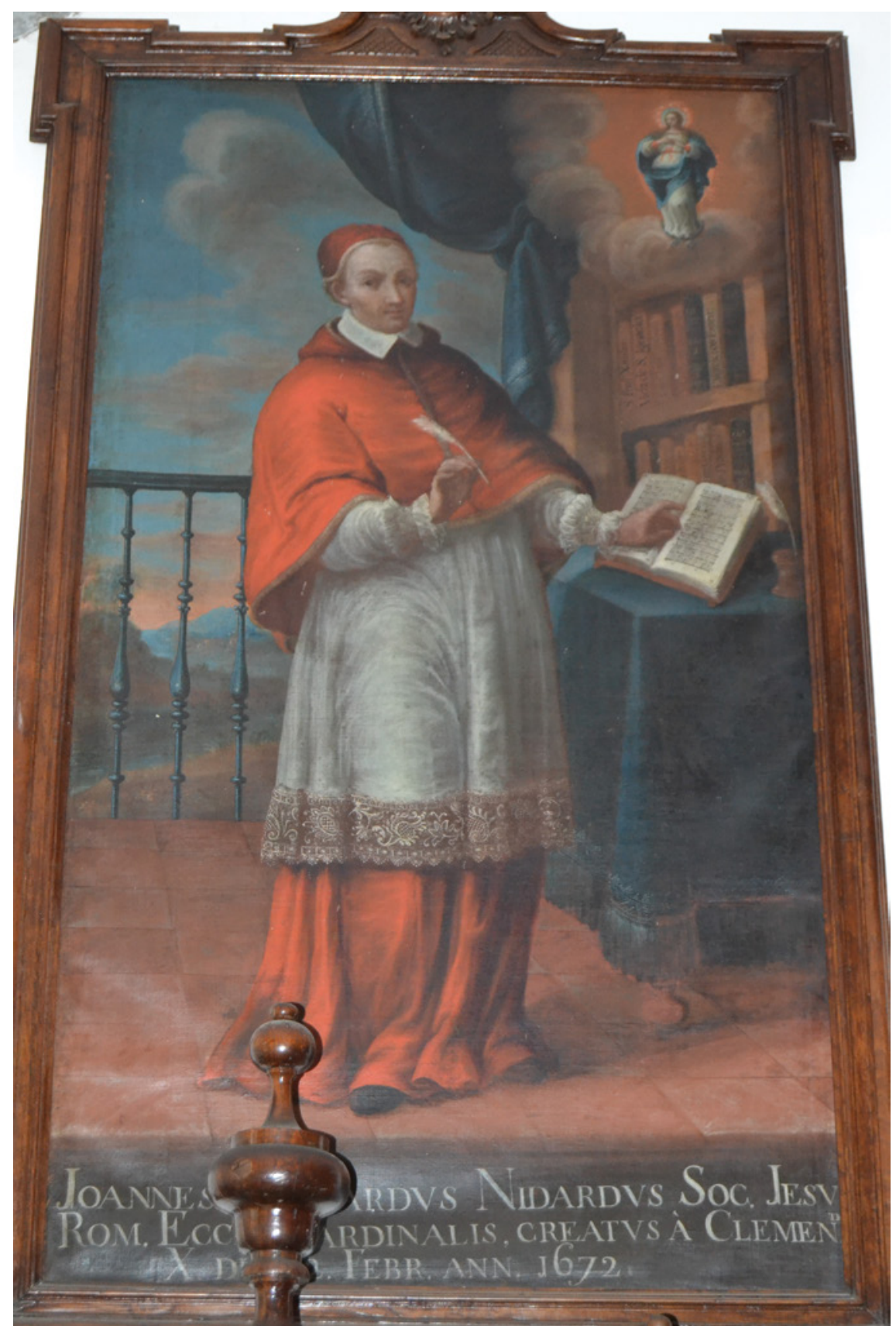

FIGURE 1 Portrait of Cardinal Nidhard (eighteenth century). Jesuit Community of Loyola (Guipúzcua, Spain)

PHOTO BY THE AUTHOR 
(6o6-67), Saint Thomas of Villanueva (1488-1555), Saint Bonaventure (122174), Saint Bernardino (1380-1444), and Saint Epifanio (310-403). There is one that says "Damianus," which may refer to Saint Peter Damien (1007-72), who was bishop of Ostia and cardinal; it is not possible to discern the author of the twelfth book. Above them hangs a canvas of Immaculate Mary, of which Nithard was a defender. In the lower right corner, there is a sign, supported by an angel, which explains more about the character portrayed in the painting.

The second canvas depicts the cardinal standing next to a table on which there is a book, seemingly written by Nithard, which is opened on page "xii." Behind the table, there is a bookcase containing several books, but the only volumes that are visible are one by St. Francis Xavier $(1506-52)$, others by St. Ignatius of Loyola (c.1491-56), and one copy of the Spiritual Exercises. Above them, there is a break in which Immaculate Mary stands on a crescent moon while stepping on a snake. Behind the cardinal, a balcony opens out toward a landscape, with a large blue curtain knotted to the right. In the lower part, there is the name of Pope Clement $\mathrm{x}(\mathrm{r} .1670-76)$, who made Nithard cardinal, and the date of the consistory, February 22, 1672 .

Through these works of art, we can deduce that Nithard was of a serene character, a student of theological texts. We know that he was a writer, because in both cases he is depicted writing. In both cases, it is clearly stated that he is a Jesuit, although some scholars have said that he ceased to be so when he was consecrated archbishop of Edessa at the request of the superior general. But in the first of the canvases he asserts such a status himself and, in the second, it is asserted by the Jesuits themselves who commissioned the work.

\section{First Years}

Johann Eberhard was born on December 8, 1607, in Upper Austria, in Falkenstein. He is known by several variations of his surname: Nithard, Nidhard, Neithard, Nitardo, Nitarto, Nidoardo, Nidardo. He was the son of an imperial general commissioner who would be commissioned by Emperor Ferdinand II (r.1619-37) to eradicate Protestantism in certain areas of Austria. ${ }^{3}$ After helping his father in this task as a young man, he was later enlisted, for a period of two years, in the army of the Catholic League with the rank of ensign. When the Catholic League was dissolved, he went to the court of Vienna to join another army that was planning to fight the state of Milan. It was then, as he recounts in his memoirs, that he encountered the work of Thomas à Kempis

3 MS 8344, vol. 1, Relación histórica de las cosas que han sucedido en España [...], fols. $46^{\mathrm{v}}-47^{\mathrm{r}}$. 
(1379/80-1471), Imitatio Christi, which strongly affected his soul and led to his eventual conversion. He resumed his studies of letters at the University of Graz (Styria). Once concluded, he was admitted to the novitiate of the Society of Jesus on October 15,1631 . After studying, he was ordained a priest in 1639 at Graz.

Nithard was assigned to teach at the aforementioned university, where he gained fame as a professor of philosophy, ethics, canon law, dogmatic theology, and rhetoric. When Emperor Ferdinand III (r.1637-57) wanted a teacher and confessor for his children, Archdukes Leopoldo Ignacio (1640-1705) and María Ana (1634-96), he asked the Jesuits for a candidate. Among those presented, Nithard was elected.

When Archduchess María Ana had to move to Spain to marry Philip IV (r.1621-65), the emperor commissioned Nithard to accompany his daughter, instructing him that "from now on [he] should be as a father in temporal matters with his daughter the queen with the same zeal with which he has fulfilled his spiritual fatherhood with his holy and laudable education."4 However, comments made by Countess d'Aulnoy (1651-1705), Father Nithard's contemporary, seem to imply that this task was actually achieved by the influence of other people surrounding the emperor:

Only his ingenuity served him to prosper, for he was ductile, complacent, studied the character of those he needed, and never departed from the ends he pursued. In Vienna, many ladies of the court appointed him their spiritual director and did not give up until he was able to get him on good graces with the emperor, so much and so favorably they spoke about him that they finally managed to allow the queen to take him with her. ${ }^{5}$

Archduchess María Ana, accompanied by her confessor, arrived in Spain on August 27, 1649. She made her entry into the villa of Madrid on October 3. Nithard went to stay in the novitiate of the Society of Jesus, without any prerogatives or advantages. He spent alms on the adornment of the church of the aforementioned novitiate.

4 MS 8344, vol. 1, Relación histórica, fol. $5^{1^{\mathrm{r}}}$.

5 M. Nieto Muñoz, ed., Diario del conde de Pötting, embajador del Sacro Imperio en Madrid (1664-1674) (Madrid: MAE, 1990-93), 1:8. See also María del Carmen Sáenz Berceo, Confesionario y poder en la España del siglo XVII: Juan Everardo Nithard (Logroño: Universidad de La Rioja, 2014), 17n16. 
Sixteen years would pass before the death of Philip IV. In the meantime, Nithard continued to exercise the office of confessor. Having acquired the confidence of the king, he was also appointed member of several boards to discuss particular issues, such as the Junta de Reformación, ${ }^{6}$ created by the countduke of Olivares in 1622 , the Junta de Medios, ${ }^{7}$ and the Junta de Reservas, ${ }^{8}$ which was responsible for the welfare of Spanish subjects. He was also on the board established to promote the declaration of the dogma of the immaculate conception. The trust placed in him, as Nithard tells us in his memoirs, was such that the emperor, due to the absence of his ambassador, asked him to take care of some issues to which he "corresponded with equal satisfaction to the confidence that their Majesties expected of him."9

According to the diary of the count of Pötting (1627-78), the ambassador of the Holy Roman Empire in Madrid, in 1663 Nithard had tried to return to Vienna, but the emperor rejected his request because, among other things, if the king had died "the queen would not have a trustworthy person beside her."10 Likewise, the ambassador tells us that Nithard is not "skilled in matters of temporal policy and does not sufficiently take into account the consequentias actionum, but he is certainly a very pious and exemplary religious who probably will not pretend to intrude into anything."11

During this time, Nithard became an intermediary between the superior general of the Society of Jesus, Giovanni Paolo Oliva (in office 1661-81), and the court of Spain, which supported the Jesuits. ${ }^{12}$ He would thus begin "to intervene discreetly in politics directed, from Rome, by the general of the Society of Jesus."13

During the final days of Philip IV, Nithard remained physically close to the monarch. He assisted the king in his death, at dawn on September 17, 1665,

$6 \quad$ It set up to examine and act upon proposals for socio-economic reform.

$7 \quad$ The Junta de Medios was responsible for regulating tributes.

8 The Junta de Reservas reviewed nobles' requests for the exemption from taxes.

$9 \quad$ MS 8344, vol. 1, Relación histórica, fol. $54^{\mathrm{r}}$.

10 Muñoz, Diario del conde de Pötting, 1:8; Sáenz, Confesionario y poder en la España, 25.

11 Julián J. Lozano Navarro, La Compañía de Jesús y el poder en la España de los Austrias (Madrid: Cátedra, 2005), 301.

12 Lozano, La Compañía de Jesús, 300.

13 Julián J. Lozano Navarro, "Dos embajadores del rey católico en la Roma del siglo XVII: Los cardenales Trivulzio y Nithard; Una perspectiva comparada," Chronica nova: Revista de historia moderna de la Universidad de Granada 42 (2016): 137-66, here 142. See also Lozano Navarro, "Confesionario e influencia política: La Compañía de Jesús y la dirección espiritual de princesas y soberanas durante el barroco," in Los jesuitas: Religión, política y educación (siglos XVI-XVIII), ed. José Martínez Millán, Henar Pizarro Llorente, and Esther Jiménez Pablo (Madrid: Universidad Pontificia Comillas, 2012), 2:183-205, here 2:202. 
which tells us about the degree of familiarity between the two men. When the monarch eventually passed away, Nithard left the royal chamber and went to the chapel of the head waitress to say a requiem Mass. Then he went to tell the queen that the king had died.

With the passing of the king at age sixty-two, Mariana of Austria became regent because the new king — Charles II (r.1665-170o)—was only four years old. The queen, who was not aware of the country's political problems, began consulting her confessor for advice. This was the beginning of his rise to the highest religious and civil positions, in which the queen effectively placed the government in his hands. This turn of events led to criticisms being raised against him, albeit more due to social prejudice than anything else, because Spanish high society took offense at someone with a lack of lineage occupying such a position, particularly as he was also a foreigner. Very soon, these prejudices spread to the Spanish people at large, who came to exaggerate Nithard's low pedigree. It was of little use that Nithard claimed the brief granted by Emperor Ferdinand III to his brother in the Diet of Regensburg on April 18, 1654, where it was stated that his family did have lineage.

The year 1665 thus marks the beginning of Nithard's political rise. He was appointed state councilor at the end of the aforementioned year, appearing on the list of the seven new members promoted to councilors on January 16,1666 , sworn in on January 19 with the duke of Albuquerque, Cardinal Girolamo Colonna (1604-66), the duke of Montalto, and the count of Ayala. He was also made general inquisitor, a position enabling him to become a full member of the government board — created by Philip IV in his will in order to help during the regency - and, subsequently, valido of the ruling queen. He was fifty-eight years old at the time, having established a brilliant academic career as well as gaining wide-ranging political experience in the courts of Vienna and Madrid. However, he was criticized for ignorance, lack of worldly knowledge, and, thus, being unsuitable for the tasks at hand. In the sources, this once brilliant university professor now became an ignorant and incapable administrator. $\mathrm{He}$ was described as "not a good judge of character, with which he would discard what he had to choose and choose what he had to discard."14 The attacks became so widespread that they were even echoed by some Jesuits in Madrid, such as Jacinto Pérez, who in a letter to Superior General Oliva, dated November 28,1665 , said that "many have already doubted that the subject's talent is not as great as imagined."15

14 Lozano Navarro, "Dos embajadores del rey," 147.

15 ARSI, Hisp. 92. Histórica 1534-1704, fols. $42^{\mathrm{v}}-44^{\mathrm{r}}$. Letter from the Jesuit Jacinto Pérez to Superior General Oliva, Madrid, November 28, 1665, fol. 43v. See also Julián J. Lozano Navarro, 
One of the weaknesses of Nithard's government was its failure to create a solid party in his favor that would be strong enough to support him in times of difficulty. Among his supporters were the admiral of Castile, the count of Villaumbrosa or the marquise of Vélez. Yet his enemies were simultaneously creating a vision of the Jesuit that has found its way into contemporary scholarship, as a "man of disastrous government and who should never have held the public office in which he interfered." 6

In September 1666, Nithard was appointed general inquisitor, but not before having been naturalized as a Spanish subject, which was approved by most of the cities that had a vote in the court. This naturalization appeared in the royal decree of September 20, 1666. Pope Alexander VII (r.1655-67), at the request of the queen, confirmed the election of the general inquisitor by issuing a brief conferring said dignity on Nithard on October $15,1666 .{ }^{17}$ This was the source of great consternation among the high Spanish clergy who aspired to that position. In addition, he was dispensed from the vow of poverty, because the pope granted him the power to receive up to ten thousand ducats as the ecclesiastical income for this position.

The Jesuit curia in Rome made many attempts to dissuade Nithard from accepting this appointment, as it directly opposed the private vow of not accepting dignities outside the Society. Thus, Oliva wrote him a letter on February 12, 1666 and another dated July 7 :

Shake off intrepidly Your Reverence the position of supreme inquisitor and be assured that you will be from now on more distinguished by the rejection of this vast dignity, than would be the most illustrious heroes in obtaining it. The magnanimous contempt of dignities elevates Your Reverence to the highest heights of the Society. Everardo is presented to me higher up to the sky by the repudiation of human honors, than other illustrious of the earth, when they admit the miter offered to them. Otherwise Your Reverence do not forget to attend the Serene Queen with your advice and prudence, that the city of Rome confesses to being

"Valido defenestrado, embajador despreciado: Algunas reflexiones sobre la deslegitimación política en torno al cardenal Juan Everardo Nithard," Krypton: Identità, potere, rappresentazioni 2 (2013): 19-31, here 23.

16 Lozano Navarro, "Dos embajadores del rey," 147.

17 Astrain says that a copy of the decree and the brief is conserved toward the beginning of De rebus Cardinalis Nidardi. 
distinguished in her person. As long as you keep yourself higher than all the honors offered, laugh at the barking of envy.18

The superior general's pleas did not change his mind, and, as we have already seen, he ultimately accepted the position. He took up the role of general inquisitor of the kingdom on Saturday, November 13, 1666, which enabled him to be a full member of the governing board, as another member of the board tells us, the vice chancellor of Aragon: "Sunday, 14 [of November]. Father Everardo Nihardo of the Society of Jesus swore on the board as general inquisitor, having taken possession of this office. I could not assist."19

According to Lozano, Nithard aimed to "destroy [the board] from within in order to put all governmental power in the hands of the regent. And on his own, by default." ${ }^{20}$ This was the moment when the campaign against him truly began, one that questioned his position as a new valido. All this was orchestrated by Don Juan José de Austria (1629-79), who aspired to lead the monarchy. He twice planned to assassinate the confessor, failing on both occasions. The first attempt was on February 17, 1668, and, the second, in May of the same year.

The situation became so tense that fear of civil war was growing. The pope intervened by sending two briefs, one to Nithard and the other to José de Austria through the nunciature. The nuncio urged Nithard to renounce his posts and leave Spain, to which Nithard replied that "he was placed in the hands of God, for whose cause his willing to suffer much more, and that by Divine Mercy, death did not frighten him, death which he had waited for so long, with no more certainty than his conscience,"21 but that, in the end, he would be willing to obey whatever the queen ordered.

Prince Charles II did not accept such excuses and threatened to enter with his three hundred-man army in Madrid. ${ }^{22}$ He also had popular support. According to a printed story that describes the circumstances of that moment, the prince affirmed that if the confessor did not go out "through the door, he

18 ARsi, Hist. Soc. 55 (I), De rebus Card. Nidardi, 1666-1680, fol. 1. See also Ángel Santos Hernández, Jesuitas y obispados: La Compañía de Jesús y las dignidades eclesiásticas (Madrid: Universidad Pontificia Comillas, 1998), 172.

19 G. Grespí de Valldaura and Bosch Labrús, Diario del señor D. Cristóval Crespí, presidente del Consejo de Aragón (Madrid: Boletín Oficial del Estado, 2012), 351. See also Sáenz, Confesionario y poder en la España, $39 n 70$.

$20 \quad$ Lozano Navarro, "Valido defenestrado, embajador despreciado," 21.

21 Relación puntual y verdadera de la salida del Padre Iuan Euerardo, confessor de la Reyna nuestra Señora, el Lunes 25 de Febrero deste año de 1669 , fol. $2^{\mathrm{r}}$.

22 Gabriel Maura Gamazo, Carlos II y su corte: Ensayo de reconstrucción biográfica (Madrid: Boletín Oficial del Estado y Real Academia de la Historia, 2018), 9. 
would go out the window, and Don Juan would enter Madrid to execute him in his name."23

Thus, the regent had to give up and sign a decree, in the old alcazar of Madrid, on the morning of February $25,1669,{ }^{24}$ by which Nithard was dismissed from all his government positions. At that time, the general inquisitor, as was his custom, was at a meeting of the Council of the Inquisition, at which he was informed of the situation. The council admitted that Nithard "was an innocent and holy man and that he had fulfilled all his obligations, was unfortunate and not well seen." ${ }^{25}$ Therefore, on the one hand, the council recognized his worth as a person but, on the other, it also recognized that he would nevertheless have to resign from his public duties.

Nithard retired to his house, where he received the support and advice of his fellow Jesuits and a visit from his friend, the admiral of Castile.

We know what happened later from the reports of José de Rivera (d.1670), secretary of the council and the Chamber of the Inquisition. ${ }^{26}$ In the afternoon, Nithard went to say goodbye to the Council of the Inquisition that would accompany him to the first stop at Fuencarral, two leagues from Madrid. Before doing so, he tried to visit the queen and her son to say goodbye, but she sent him a note in German asking him not to attend, because she feared

that your coming to say goodbye to me and the king my son, could cause some disturbance in the present circumstances, and that my heart would be broken in pain at seeing these; pure need and violence have forced me to be separated from you [...], do not forget to remember me in your holy sacrifices and prayers, as I will also keep you in mind always to favor you, since violence separates us and keeps us apart [...]. I remain in all times and circumstances your queen and daughter of confession. ${ }^{27}$

Cardinal Aragon went to pick him up, as stipulated, at half past four in the afternoon. He was accompanied by two of his nephews, the duke of Aveyro and Maqueda, and the marquis of Carpio and Liche. They left Madrid on the road to Fuencarral, where Nithard was lodged at the house of the parish priest. ${ }^{28} \mathrm{He}$

\footnotetext{
23 Relación puntual, fol. $1^{\mathrm{v}}$.

24 Relación puntual.

25 AHN, Inquisición, libro 274, doc. 6, fol. $1004^{\mathrm{r}}$. Apartamiento del inquisidor general de esta Corte. See also Sáenz, Confesionario y poder en la España, 143.

26 AHN, Inquisición, libro 364. See also Sáenz, Confesionario y poder en la España, 144.

27 Quoted by Lozano Navarro, "Una embajada controvertida," 271.

28 Archivo Loyola, fondo $\mathrm{H}^{\circ}$, leg. 20, fol. 54. See also Sáenz, Confesionario y poder en la España, 152 .
} 
had agreed to make the journey on the promise that he would be appointed ambassador of Spain in Rome. He arrived in Fuencarral on the twenty-sixth, a Tuesday, although we do not know exactly why this stop was made. That same day, the count of Medellín arrived to arrange everything necessary for the inquisitor's trip. In the afternoon, the carriage went to San Agustín de Guadalix, six leagues from Madrid, where he formally received the decree of expulsion. Before leaving Fuencarral, according to the memoirs, he wrote to the pope, to the superior general of the Society of Jesus, and to the emperor to give them news of what had happened. ${ }^{29}$ On the same day, he was also asked to choose between exile in Rome or Vienna, for the queen had given him a choice. On February 28, he replied that he would go to Rome. ${ }^{30}$ That afternoon, he left for Cabanillas del Rey. From there, he continued toward Loyola (Guipúzcoa), to the house of the founder of the Society. During the trip, he stopped three days in the Jesuit community of Burgos. On March 11, he arrived in Vitoria. He would pass through Mondragón until he reached the hometown of Saint Ignatius. On March 16, he wrote from this town to record that he had received the royal decree from the queen, on the eleventh day of that month, so that he could continue uninterrupted on his way to Rome.

On April 25, Nithard was at Marseille. A short time later, he would disembark in Genoa, where he wrote to the superior general, first to put himself at his service and, later, to ask that two priests of his trust, Sebastián Izquierdo and Alfonso de Alarcos (1617-79), who was attorney general of Spain, travel to meet him so that he could speak with them before entering the Eternal City. While the ceremony was being prepared to receive him in the city, Nithard stayed in a country villa a short distance from the papal capital. This privilege was courtesy of the marquis of Astorga, who was the outgoing ambassador.

Nithard arrived in Rome on May 16, 1669. He was received with honors by the outgoing ambassador, the marquis of Astorga. He stayed at the professed house of the Society of Jesus. ${ }^{31} \mathrm{He}$ was still the general inquisitor of Spain, a position that placed him at a level close to that of the archbishop of Toledo and primate of Spain. In a letter dated September 18 of that same year, he informed the

\footnotetext{
29 MSs 8351, vol. 8, Relación histórica de las cosas que han sucedido en España, fols. $20^{\mathrm{r}}-21^{\mathrm{r}}$, $25 \mathrm{ff}$.

30 AHN, Inquisición, libro 364, 157. Sáenz, Confesionario y poder en la España, 159.

$31 \quad$ MS 8352, vol. 9, Relación histórica, fol. $2^{\mathrm{r}}$.
} 
queen regent that he had left his office as general inquisitor in the hands of the holy father as she had requested, to which the marquis of Astorga can attest. ${ }^{32}$ This event took place on September 12. ${ }^{33}$

In a royal decree of July 25,1669 , the queen, with the approval of the Council of State and government board, appointed her confessor extraordinary ambassador to Clement IX. ${ }^{34}$ In the background, according to researchers, was the queen's desire for the pope to publicly rehabilitate Nithard. This, the confessor thought, would allow him to return to Madrid with the queen. But the political delegitimization campaign he had suffered in Madrid soon spread to Rome, where his lack of noble lineage was underlined along with gossip about the great fortune and jewels he had supposedly brought from Spain: "They say that he brings in money twelve thousand doubloons, and in bars of gold seventeenth pounds, and a coffer full of jewels and jewelry of great importance."35

Nithard's enemies thus chased him to the Eternal City, where they soon began pressuring the Society of Jesus so that the former confessor would be assigned to a school outside the capital.

In the meantime, Queen Mariana of Austria obtained the cardinal hat for D. Luis Manuel Fernández from Pope Clement IX, with Manuel Fernández becoming Cardinal Portocarrero (1635-1709) in the consistory of November 29, 1669. But this left an open wound in the monarch, as the holy father had not granted the purple to his confessor, Nithard. A few days later, on December 9, 1669, Pope Clement IX died, and Cardinal Portocarrero began preparing for his trip to Rome for the conclave, being the last to arrive. Clement $\mathrm{X}$ would be elected pope after four months of conclave (it began on November 20, 1669 and ended on April 29 with the election of Cardinal Emilio Altieri). The election of the new pontiff took a long time because, when the Spanish cardinal arrived in Rome, on April 18 or 19, the conclave that had begun in December was in deadlock. With his entry into the conclave, the situation was unlocked. The new pontiff was crowned the vicar of Christ on May 11, 1670 by Cardinals Maidalchini (1631-1700) and Portocarrero.

On June 3,1670 , the queen wrote to Nithard informing him that she was doing her best to get him promoted to bishop of Agrigento in Sicily, a see that was vacant. In another letter, dated the eighteenth of that same month, she insisted

32 MS 8352, vol. 9, Relación histórica, fols. $91^{\mathrm{v}}-92^{\mathrm{r}}$.

33 Manuel Muñoz Rojo, Un hombre para la historia: El Cardenal Portocarrero (1635-1709) (Córdoba: Universidad, 2019), 133.

34 MS 8352, vol. 9, Relación histórica, fol. $110^{\mathrm{r}}$.

35 Discurso político o críticas reflexiones sobre la conducta del señor Don Juan de Austria, Semanario Erudito (1787), tome 4, 235. Lozano Navarro, "Valido defenestrado, embajador despreciado," 23. 
on this, specifying that she expected that the appointment would come with the cardinalate, although she knew that

you will resist this provision because of your natural humility and disgust of all kinds of dignities; but it is necessary to direct you to them, in order to make the world understand that your procedures have been justified, and the testimonies that have been raised against you are false. ${ }^{36}$

In a letter dated August 2 of that year, Nithard tells Don Pedro Fernández del Campo (1616-80) his objection to the bishopric of Agrigento, describing it as a dignity he could not accept in view of his vows unless he was "required by His Holiness under penalty of sin." ${ }^{37}$ In the end, his objections to this appointment were accepted.

Within months of Clement $X$ being crowned, there came a fealty embassy of the duke of Segorbe and Cardona, Pedro Antonio de Aragón (1611-90), who was viceroy of Naples from 1666 . The embassy began on January 3,1671 , the day he left for Rome, and would end a month and a half later, on February 18. This would be the first embassy to be made on behalf of King Charles II, still a minor. ${ }^{38}$ During this visit, the viceroy met with the queen's confessor, Nithard, so it can be inferred that the duke of Segorbe and Cardona was already aware of the immediate coming of the Spanish embassy to Rome.

For this reason, at the request of Queen Mariana of Austria, the Council of State deliberated on October 2 whether Nithard was to be appointed interim extraordinary ambassador while the marquis of Carpio decided to move to Italy as an ordinary ambassador. Although divided, the councilors ultimately decided, by a clear majority, not to accept the queen's request. They were more in favor of appointing Cardinal Portocarrero or any other cardinal, even an Italian. ${ }^{39}$ The nuncio who was in Madrid expressed to the pope his disagreement at said appointment, writing that "everyone will consider how dissonant a man of such mediocrity should be appointed to represent a monarchy."40 Nevertheless, on October 13, 1671, the queen regent appointed him as an interim

\footnotetext{
36 MS 8352, vol. 9, Relación histórica, fol. $121^{\mathrm{v}}$.

37 MS 8352, vol. 9, Relación histórica, fol. 148 $8^{\mathrm{r}}$.

38 AHN, Sección Estado, parte relativa a Roma, leg. 1837. Embajada 1640-1671: Instrucciones. See Diana Carrió Invernizzi, "La embajada de obediencia del duque de Segorbe y Cardona al papa Clemente X (1671)," Rivista storica italiana 2 (2014): 319-41, here 326.

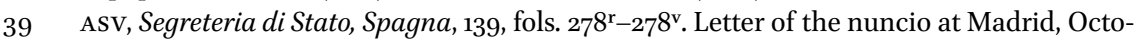
ber 23, 1671. Lozano Navarro, "Dos embajadores del rey," 162.

40 Asv, Segreteria di Stato, Spagna, 136, fols. 429-32. Madrid, July 31, 1669. Lozano Navarro, "Dos embajadores del rey," 163.
} 
extraordinary ambassador. The next day, the brief of the appointment left for Rome. It arrived on the twenty-ninth of that same month, and the news was communicated to Nithard by the marquis of Astorga. ${ }^{41}$ As Nithard himself tells us in his Memorial:

On the same morning of October 29, when the extraordinary brief arrived from Madrid with the Royal Office of the ordinary embassy for Father Confessor, Cardinal Portocarrero having heard about it was dismayed with resentment, then rushed to the professed house of the Society of Jesus, where Father Confessor was staying, and instead of congratulating him, he began to express his pain and feeling, that Her Majesty, even though he was a cardinal of the Holy Roman Church, and a native of Spain, and the confessor on the contrary for his status and in the habit of religious, and foreigner for his birth, had not commissioned him to be the interim of the ordinary embassy in Rome. This was for His Eminence an affront and a cause of great consternation and importance, by which he was forced to leave Rome and head back to Spain because it was not possible to stay in this court and suffer the discredit and humiliation that had resulted from this resolution of Her Majesty. ${ }^{42}$

It appears that Nithard was exaggerating here due to the wounds caused by his expulsion from Spain in 1669. Cardinal Portocarrero, certainly, was hurt by what happened and communicated this to the Spanish court. That letter was summarized by the Council of State in the following way:

Council of State. A letter in which Cardinal Portocarrero replies to the appointment of Juan Everardo as interim of the embassy of Rome [...] and says that he then went to visit Juan Everardo, and assured him that, once again, he would continue the friendship that he has professed to him since he lives in Rome, and that he would attend whatever was of Her Majesty's service in fulfillment of his obligations, but that he must represent to Her Majesty that only the one who attends to the Roman court runs business or is in the expectation of being able to do it, being the reward that is expected from one case to another, the foundation of

41 MS 8352, vol. 9, Relación histórica, fol. $117^{\mathrm{r}}$.

42 MS 8352, vol. 9, Relación histórica, fols. $157^{\mathrm{r}}-157^{\mathrm{v}}$. 
all interests, $[. .$.$] had come to think it would be service of Her Majesty to$ ask for a license to come to Spain $[\ldots] .^{43}$

This reveals the offense felt by the cardinal and shows that this affront was not only to his person but also to the Roman curia. With this appointment, the Vatican would have to deal with a simple Jesuit confessor without any recognition, something unusual for the time, because that position was occupied by someone with a higher ecclesiastical dignity, namely a cardinal. Moreover, it was expected that the person in this position would come from high society, which is why, in addition to offending Cardinal Portocarrero, it was also offensive to the Spanish high nobility, because a foreigner had been chosen to represent the interests of the Spanish kingdom.

Both the queen and the supreme pontiff consequently sought to resolve this situation. Accordingly, they sought to raise Nithard to a bishopric or archbishopric and then make him a cardinal. In this way, according to Manuel Muñoz Rojo: "Everything that Madrid denied him he got in Rome."44 This also enabled a period of coexistence between Portocarrero and Nithard between 1670 and 1677, the date on which the seventh marquis of Carpio finally assumed the Spanish embassy in Rome.

Still, in his memoirs, Nithard shows a certain resistance to his appointment, as was the case before. In his Memorial, Nithard tells us how, at the end, by order of Clement X, Cardinal Michelangelo Ricci (1619-82) came to the professed house where he was living and communicated the formal precept of accepting the title and dignity of the archbishop of Edessa in partibus infidelium. In that way, he was empowered to carry "the exercise of the embassy while condescending to the request of the Catholic queen." 45 Although he was not yet considered sufficiently decent to be an ambassador, at least this dignity would allow him to have a more prestigious position within the pontifical protocol expectations of the seventeenth century. He described the scene as follows:

They responded to such news for His Excellency with abundant tears and devout sighs coming from their chests because they lacked words to describe what they were feeling. He considered that as a Catholic, he had the obligation to obey the supreme pontiff, but it was hard for him to divest himself of the venerable habit of his beloved religion and, thus,

43 AGs, Estado, leg. 3045, apud Leticia Ma de Frutos, El templo de la fama [...], 159n159. See also Muñoz, Un hombre para la historia, 135 .

44 Muñoz, Un hombre para la historia, 135.

45 MS 8352, vol. 9, Relación histórica, fol. $159^{\mathrm{r}}$. 
fluctuating in a sea of confusion, with which he was agitated with contrary affections, perplexed, for a long time he stopped to consider what to do. Until, once he had recovered his breath, he asked the cardinal to suspend the imposition of the precept at that time so as to give him time to represent to His Holiness his reasons to oppose the appointment. This he did by renouncing the ambassadorship that was the only reason he had taken off his religious habit, begging His Holiness to deign to choose another mean between those proposed. However, this was rejected, and once again the cardinal returned to effectively impose the apostolic mandate, to which Your Excellency responded in this way:

So far I represented to His Holiness the reasons dictated by the love of my vocation, state and habit so as to keep me in it, as I only wished, always indifferent to exercising what God, by his vicar and my superiors would like to send to me, and seeing now that his divine Majesty declares his will and command it to me, who can only command it to me, I must surrender and surrender my humility with blind obedience to what is commanded of me.

Finally, Nithard accepted the title - the letter continues - and tried, in order to receive with dignity the sacrosanct archbishop's character, to withdraw from temporal activities so as to pray and do the Spiritual Exercises. He did this because he wanted to enter the new state and prepare for the approaching consecration. ${ }^{46}$

But, before doing so, Nithard had to overcome another setback, namely the opposition of Oliva, superior general of the Society of Jesus, who tried to present his arguments against the appointment to the holy father, but he did not receive him, as the pope wanted to please the queen. These were the words of the superior general to Cardinal Altieri, dated November 7,1671 :

Fr. Everardo, confessor of the queen, lives very distressed to be excluded from the feet of our Lord and the door of Your Excellency. You refuse to hear us in such an important matter to him, and to us. I humbly plead for this to Your Excellency to have mercy on his laments and our dangers, especially promising to accept the dignity provided they hear him before. I add that when His Holiness and Your Excellency deign to receive him, I will perhaps propose a solution that would satisfy you fully and will not open a door to the Society which then no other pontiff can annul or close.

46 ARSI, Hist. Soc., 56, fols. 258-59. See also Santos Hernández, Jesuitas y obispados, 174. 
In similar cases, the general of the Society has always been benignly heard as His Holiness did lately when they bothered him to create bishop of Agrigento the very afflicted father himself. And first, Alexander VII, before forcing the father to accept the honorable burden of the Supreme Inquisition of Spain, communicated with me the whole business, humbling himself until he wanted consent, as Patriarch Ugolino can testify. We will all obey with the fullest humility the Universal Father of the Church; but we hope that with the intercession of Your Excellency, he will be a loving father to us, as he has always been shown, accepting our supplications and hearing our proposals. ${ }^{47}$

But seeing that there was no other possible solution than to accept, Oliva proposed a remedy through the cardinal-nephew. Nithard could accept the miter, as the queen of Spain and the pope wanted, but from that moment on he would not be considered a member of the order, ${ }^{48}$ although in another document it is said that he would be "subtracted from the obedience of the Society," ${ }^{\prime 9}$ which allows us to understand why he was always considered a Jesuit. In addition, the superior general asked, in order to protect the order,

that, finally, His Holiness wants more than ever to conserve and protect the Society of Jesus, by keeping its privilege of not admitting bishoprics, or titles except in the countries of infidels, where the dignity is pure suffering. Gracefully will the Society keep perpetual memory of this in its archives and in the hearts of all its sons. ${ }^{50}$

Nithard tells us about the process of his appointment on November 16, 1671:

The process, which is customary on these occasions, was done. Fr. Confessor made the profession of faith at the novitiate of St. Andrew, of the Society of Jesus, and was conducted [marginal note: on November 16, 1671 (in the morning in which this provision of the church of Edessa was published in the person of Fr. Confessor by the secret consistory)] by the masters of ceremonies to the audience with His Holiness, in which His Beatitude put on the surplice saying to Fr. Confessor that he should not

47 ARSI, Hist. Soc., 56, fol. 248. Santos Hernández, Jesuitas y obispados, 174-75.

48 ARsi, Hist. Soc. 55 (1), De Rebus Card. Nidardi, $1666-1680$, fols. $32,35^{\mathrm{r}}-35^{\mathrm{v}}$. Letters of Oliva to Cardinal Altieri, Rome, September 1671. See also Lozano Navarro, "Valido defenestrado, embajador despreciado," 27.

49 ARSI, Hist. Soc., 56, fol. 245. Santos Hernández, Jesuitas y obispados, 175.

5o ARSI, Hist. Soc., 56, fol. 245. Santos Hernández, Jesuitas y obispados, 175. 
be unhappy that His Holiness forced him to move out of habit, because [thus] he had agreed to the service of God, of the Holy See, and of the Catholic queen in order to exercise the office of ambassador with more decency. To all of these, Fr. Confessor responded with tears in his eyes saying that only holy obedience, which he owed to the precepts of His Holiness, could have forced him to accept this new state. ${ }^{51}$

On January 24, 1672, the solemn consecration as archbishop of Edessa took place by the hands of Cardinal Federico Sforza (1603-76) and the archbishops of Antioch and Jerusalem, Cardinals Altovite and Egidio Colonna (1607-86). The event would be attended, among others, by the marquis of Astorga, Cardinal Portocarrero, the Society's superior general, and numerous members of the Italian nobility.

The first pontifical hearing took place on January 31. The event was preceded by a typical display of Hispanic pomp when the event took place in Rome. Accordingly, the newly consecrated archbishop of Edessa, surrounded by servants, went to the Quirinal Palace by carriage, which was decorated with black velvet to remind viewers that the person within the carriage was a religious. Clement X blessed him during the audience. Once the audience concluded, Nithard went to pay a courtesy visit to Queen Christina of Sweden (1632-54), as well as visiting the Vatican and the churches of Santiago de los Españoles in Piazza Navona and Our Lady of Montserrat.

Yet the archbishopric was still insufficient for an ambassador from Spain, the cardinalate was needed. But on this issue, Clement X stalled because the nuncio in Madrid had already expressed his dismay at Nithard's government:

The lousy state of this court, the incapacity of the queen in command, her credulity to the confessor, inexperienced in government, the lack of care that is used in the good education of the king, the contempt for the good subjects and especially the lord count of Castrillo, remove without care, the election of the new president of Castile, unfit for such office [...] the disunity in the Royal Council and the board. ${ }^{52}$

This resistance caused Queen Mariana to write to the cardinal-nephew expressing her pain and her wishes regarding this issue:

$5^{1} \quad$ MS 8352, vol. 9, Relación histórica, fols. $162^{\mathrm{r}}-162^{\mathrm{v}}$.

$5^{2}$ ASV, Segreteria di Stato, Spagna, 136, fol. 271. Nuncio Visconti to the pope, Madrid, October 13, 1668. See also Julián J Lozano Navarro, "La Monarquía española y la sede vacante de 1676," Tiempos modernos: Revista electrónica de historia moderna 20 (2010): 1-27, 6n11. 
Of particular pain is to see that what with so much instance and just motives I have begged from His Beatitude in order to be granted this grace is less advanced in his holy spirit than I desire and should expect out of his utmost righteousness and your good jobs. ${ }^{53}$

Thus, on May 16, 1672, four months later, according to Nithard's Memorial, he was "decorated with the sacred purple," ${ }^{4}$ although contemporary researchers point to May $25 \cdot{ }^{55}$ In the consistory in which the appointment was communicated, Cardinal Portocarrero was present. We have to frame this within the context of the death of Luis Guillén de Moncada y Aragón, Cardinal Moncada (1614-72). In this way, Pope Clement X made the cardinal the regent's candidate, and the queen, in turn, granted the title and status of cardinal protector of Spain to Cardinal Portocarrero, a title that previously belonged to Cardinal Moncada.

On November 22, 1672, Nithard was made cardinal. It was at this time that his work as an interim extraordinary ambassador properly began. But this work would not be easy because it did not have the support of the Spanish court or the State Council. In addition, as should already be clear, he did not have the support of the superior general of the Society of Jesus, Oliva.

At the ceremony of creation as cardinal, Nithard received the cap and the red hat that identified him as the new cardinal of the Catholic Church. The ceremony of the kissing of feet and hands of the holy father also took place in the same religious act.

Later in the secret consistory, where only Pope Clement $\mathrm{X}$ would be present with the new cardinals, Nithard received his title and his responsibility within the Roman curia. In this consistory, the ceremony of closing and opening the mouth was celebrated, "so that everything that has to be talked about between the pope and the cardinals of the Holy College is said, or is not said, except with the approval of the holy father and in authorized places." ${ }^{n 6}$ And, later, the pontiff granted the title of the church of Rome.

The situation of the ambassador did not improve, since he did not have the support of the State Council, which constantly disavowed him and always expressed a desire to replace him as soon as possible. He also had to fight against the lack of collaboration with the viceroy of Naples, who, at that time, was the marquis of Astorga, particularly in the provision of financial support. Thus, for

ASv, Segreteria di Stato, lettere di principi, vol. 97. Madrid, December 19, 1671. Lozano Navarro, "La Monarquía española y la sede vacante," 6.

54 MS 8352, vol. 9, Relación histórica, fol. $175^{\mathrm{r}}$.

55 Lozano Navarro, "Valido defenestrado, embajador despreciado," 27.

56 Muñoz, Un hombre para la historia, 128. 
example, in June 1673, the ambassador urgently needed four thousand ducats to cover the extraordinary expenses caused by the death of Empress Margarita Teresa de Austria (r.1666-73). In the end, the State Council agreed to provide this amount through the marquis of Astorga, but the viceroy turned a deaf ear. ${ }^{57}$ The situation worsened in such a way that by December 1676 the debt owed to the marquis amounted to 560,516 silver escudos in Roman currency. ${ }^{58}$

Between 1672 and 1676 , the new interim extraordinary ambassador was in charge of organizing the tribute to the holy father of the hacanea or chineathat is, the ceremony for the collection of the feudal rights of the Holy See on the kingdom of Naples - which would take place on the feast of St. Peter on June 29. But there were numerous disagreements with the Italian nobility that in some cases developed into diplomatic conflict. From Madrid, in 1673, Nithard was given clear instructions on how to proceed with the delivery of the hacanea. ${ }^{59}$ The Italian princes took advantage of the appointment of Nithard to disavow him.

An international event also took place during Nithard's embassy in Rome that would mark his work as ambassador: Messina's rebellion against Spain (1674-78). The uprising took on an international character due to France's support of the rebels' cause. Ambassador Nithard, as well as the viceroy of Naples, the marquis of Astorga, tried to have Pope Clement $\mathrm{X}$ assist them with his galleys, to which the supreme pontiff refused, claiming he could not assist in fights among Christians, a response that angered the ambassador. Tuscany and Venice also refused to provide the help requested. That is why Nithard and the marquis had to work together to recruit people to quell the rebellion. This problem would linger in the background during the celebration of the next conclave.

Another reason for the disagreement between Madrid and the ambassador was the conflict between Nithard and the main Roman nobleman who was loyal to Spain, Constable Colonna. The conflict started as a result of the ambassador's anger that the constable had left Rome by saying goodbye to the French ambassador rather than him as Spain's ambassador, to which Colonna reciprocated. However, the cardinal was not willing to compromise and asked that the princes of Palestrina and Savelli not go to see the constable. This did not please Madrid, causing Nithard to compromise, albeit reluctantly. The final reconciliation came when Lorenzo Onofrio Colonna carried the chinea in 1675 .

57 AGs, Estado: Roma, leg. 305o, s/f. Letter of Nithard to the king, Rome, December 28, 1675. Lozano Navarro, "Dos embajadores del rey," 163.

58 AGs, Estado, Roma, leg. 3064, Consultation of the council, Madrid, December 2, 1676. Lozano Navarro, "Valido defenestrado, embajador despreciado," 27.

59 AgmaE, Archivo Santa Sede, leg 91. Muñoz, Un hombre para la historia, 141. 
Another reason for the extraordinary ambassador's trouble was the celebration of Easter in 1676, which was traditionally celebrated by the Spanish community in Rome. But due to Spain's economic difficulties, it was decided that the Spanish community should not be placed in charge of the celebrations. The cardinal did not support this decision, writing that

it was not good to manifest so publicly the impoverishment of the Spanish nation, waiting on divine mercy to help us. I would contribute on my part and request all the means that could be possible [...] and not show our weakness even in times when the Catholic monarchy is so diminished. ${ }^{60}$

Despite attempting to do his work well, some of the cardinal's diplomatic mistakes increased the contempt many held for him and led him to gain even less favor from the State Council, as has already been made clear. Thus, when Pope Clement X's gout worsened in April 1676, Nithard asked for instructions on how he should act in the face of the pontiff's death, although he had been warning since 1672 of the pope's poor state of health, to which the Council of State replied: "The election of the supreme pontiff is made by allowing the Sacred College to work freely, contributing $[\ldots]$ with all the honest and natural means allowed to the assumption of the most benevolent." ${ }^{\prime 1}$ But this was an answer that could be given to anyone, and it was almost certainly the case that Cardinal Portocarrero and other supporters of the Hispanic crown were being informed of how they should truly act. Let us recall that Spain, along with France and the emperor, had a privilege within the conclave: the Ius exclusivae that allowed them to exclude a candidate from the election if he was contrary to their interests. Hence the desire of Nithard to receive information on how to act.

Pope Clement $\mathrm{x}$ died on July 22, 1676 . This put in motion the mechanisms for organizing and holding the conclave in which his successor was elected. The first thing that was done, of course, was the solemn transfer of the pontiff's body to St. Peter's Basilica, where the corresponding Masses, processions, and release of prisoners were celebrated according to protocol. Then came the public condolences of the main Catholic nations before the Holy College. This was carried out by the ambassador of France, that of Venice, that of Portugal,

6o Quoted in Lozano Navarro, "Una embajada controvertida," 281.

61 AGs, Estado: Roma, leg, 3.052, s/f. Consultation of the council, Madrid, August 14, 1676. Lozano Navarro, "Dos embajadores del rey," 163. 
and so on, but not that of Spain, since this fell to Nithard, whose duty as cardinal was to participate in the conclave.

On Sunday, August 2, after the traditional Eucharist of the Holy Spirit, the conclave began in the Sistine Chapel. The Sacred College would be constituted by sixty-seven cardinals out of a maximum of seventy. Of the three Spanish cardinals, only two attended: Nithard and Portocarrero, since Cardinal Pascual de Aragón (1626-77) could not attend. Cardinal Nithard, as an extraordinary interim ambassador, who had no experience in this-unlike Portocarreromade an elaborate report on the possibilities of each cardinal being elected pope. ${ }^{62}$ The first part of the report was a list of the cardinals that made up the Sacred College, ordered according to their age since their elevation to the cardinalate. The second part focused on providing a testimony about each of them from the perspective of Spanish diplomacy, that is, according to their proximity or otherwise to the interests of the Hispanic crown.

Meanwhile, the diplomatic headquarters remained unattended while the ambassador was at the conclave. That is why, from Madrid, it was decided that the responsibility of the embassy remained in the hands of its secretary, Nicolás Antonio (1617-84). But being a simple secretary would not give him sufficient authority, so it was also decided that Juan Tomás Enriquez de Cabrera (1646-1705), count of Melgar and governor at that time in Milan, be sent as an extraordinary ambassador. In addition, the Council of State had appointed Cardinal Portocarrero as the voice that represented Spain in the conclave, which continues to speak to the lack of confidence in Nithard.

The conclave ended on September 21, the date on which Cardinal Benedetto Giulio Odescalchi (1611-89), of Lombard origin, who took the name Innocent XI (r.1676-89), was elected. In the memorial to the Council of State, Nithard describes him as

an angel of customs separated from all interest, great charity and giver of alms to the poor [...], very zealous of the Catholic religion always ensuring that from the Apostolic See were assisted the princes who have war with the Turk, for whose effect he has he sent many times of his own money large amounts to the king of Poland. ${ }^{63}$

62 Lozano Navarro, "La Monarquía española y la sede vacante," 11-16.

63 AGs, Estado: Roma, leg. 3052, s/f. Lozano Navarro, "La Monarquía española y la sede vacante," 17 . 
As a defect, he says that "some do not like his spirit inclined to reform Rome so that this city would serve as a source of edification and not of scandal."64

On March 13, 1677, the new ambassador from Spain, Gaspar Méndez de Haro and Fernández de Córdoba (1629-87), seventh marquis of Carpio and marquis of Eliche, arrived in Rome. The interim ambassador, Nithard, and Cardinal Portocarrero were waiting for him at the Piazza del Popolo. That day, Cardinal Nithard lost his role as an extraordinary interim ambassador. This precipitated the political disappearance of the former confessor, who would spend his time, almost exclusively, in ecclesiastical matters until his death.

Nithard died on February 1, 1681 in Rome, in the palace he had rented to the duke of Paganica. The Jesuit community of Sant'Andrea del Quirinale remained his inheritors, receiving about 244,751 reales and some works of art. ${ }^{65}$ Jesuits Fernando de Muzquiz and Juan de Ganeda were the ones designated to settle his accounts. He was buried, by his own wish, next to the altar of St. Ignatius in the church of the Gesù in Rome, in the tomb of the famous Jesuit cardinal Juan de Lugo (1583-166o).

Before concluding, it is important to return to the questions asked at the beginning of this paper about the figure of Cardinal Nithard: Who was Johann Eberhard Nithard? Who was this valido of Regent Mariana of Austria? Who was this Jesuit who became a cardinal? After reading the existing bibliography, and after an attempt to make a neutral presentation of his character, it remains difficult to reach a conclusion about who he was because we would only be approaching him from a human perspective, which seeks objectivity but begins with subjective data. As was said at the beginning of this essay, the black legend that was forged around his person is so well woven that it is extraordinarily hard to unravel, even with the existing documents. Reading his twentyone-page-long autobiography, where he justifies his political actions, is likewise of little help.

It is therefore necessary to consider whether or not we are overlooking some element from the life of this Jesuit who became a prince of the Roman Catholic Church, namely the spiritual dimension, which is something that we should not ignore in our efforts to understand a person like Nithard. We know that the formation in the Society of Jesus is long and regulated, that it not only prepares its members intellectually but also helps the Jesuit to deepen in his inner life so as to improve in every step taken in the journey toward God. As part of this

64 AGs, Estado: Roma, leg. 3052, s/f. Lozano Navarro, "La Monarquía española y la sede vacante," 17.

65 ARsi, Hist. Soc. 55 (I), De rebus Card. Nidardi, $1666-1680$, fols. $64^{\mathrm{r}}-65^{\mathrm{r}}$, January $26,1684$. Lozano Navarro, "Valido defenestrado, embajador despreciado," 30. 
formation, every Jesuit completes a month-long retreat on two occasions according to the Spiritual Exercises. This is not only a school of prayer but also a school where a Jesuit learns to configure himself with Christ. According to Jerónimo Nadal (1507-80), there are two central meditations in the Exercises: Two Standards and the Call of the Eternal King. The latter seeks to mobilize the whole person to the constant call to follow Jesus in every step of life, to a full identification with him and with the mission for the kingdom. The former makes the one doing the Exercises discern the sincerity of his following in the real world, in the midst of difficulties, in an attempt to provide him with the necessary tools to discern God's will in daily life. In this way, the Jesuit becomes more aware of his process of identification with Christ and obtains greater freedom from the powers of the world, which are simply means at the service of God and not its ultimate ends. This, together with the meditations and contemplations of the life of Jesus, configures in a special way those who complete the Spiritual Exercises. Nithard made them twice, as we have seen, once during the novitiate and once at the end of his formation stage, namely during tertianship. Although during his life we can observe how the temptations of power were always present, they were almost always means used for greater purposes, for the good of others.

Another element that would mark the spirituality of the cardinal and his life was the first part of the Formula of the Institute [1]:

He is a member of a Society founded chiefly for this purpose: to strive especially for the defense and propagation of the faith and for the progress of souls in Christian life and doctrine, by means of public preaching, lectures, and any other ministration whatsoever of the word of God, and further by means of the Spiritual Exercises, the education of children and unlettered persons in Christianity, and the spiritual consolation of Christ's faithful through hearing confessions and administering the other sacraments.

This last dimension of Jesuit ministry was very patent during his ministry as confessor to the queen regent.

All this leads us to a much better understanding of the first of the portraits described at the beginning of this paper, the one belonging to the National Museum of El Prado. The serenity of Nithard's face stems from his certainty that he has done everything possible for God given the historical circumstances of his life. During his life, he was constantly reminded that he was a foreigner in a foreign land: first in Spain (a nation to which — despite everything - he always remained faithful) and then in the Papal States. It seems that his services 
were never truly appreciated by those around him, who looked at him suspiciously, distrustful of the one they knew was different from them, one who was free from the cares of the world owing to his religious vows. His serenity, despite having gone through condemnation and insults, stemmed from the knowledge that all humiliations are the crucible in which the man of God can attempt to learn to better imitate his Lord, as he prayed in the colloquium of the Two Standards [147]. In addition, by reviewing the painting and stopping at the bookshelf in the background and contemplating the variety of theological authors, we can recognize that he was also a man who was interested in further investigating sacred scripture. He was not satisfied with mere reading of the sacred texts but sought to study them so that he could better know the God he was serving.

Embracing this more spiritual approach to Nithard, and trying to read the events of his life from this point of view, leads to the conclusion that he was a person of deep faith. We encounter a man who sought to walk through life guided by Jesuit spirituality, who possibly succumbed at times to the powers of the world but discovered that these powers where self-seeking. Furthermore, we can conclude that he was a loyal man both to the people who trusted in him, as is the case of Queen Mariana of Austria, as well as to the Kingdom of Spain, despite all the sufferings inflicted on him as general inquisitor, as a member of the board of government, as valido of the queen, as extraordinary ambassador of Spain to the Holy See, and, finally, as cardinal.

What challenge remains for posterity? To pursue the spiritual perspective in future studies of Nithard, to reread his autobiography and the existing documents about him, not as historians who seek the truth through historical data but as men of spirit, who seek in others the traces of God's footprint. For we cannot forget, as has already been suggested, that in Nithard there was always a struggle between the old man and the new man, between the earthly and the spiritual, but that he always sought to configure himself with Christ, always recognizing himself as fragile and sinful. 